\title{
Risks and Preventive Solutions for Financing of Small and Medium Enterprises under Inclusive Finance
}

\section{Dan Ma*}

Hangzhou Normal University, Hangzhou City, Zhejiang Province 311121, China. E-mail: 1754115251@qq.com

Abstract: In recent years, with the steady development of economy in China, small and medium-sized enterprises are an important part of China's economic industry, but their own characteristics make them have trouble getting financing. The emergence of inclusive finance has alleviated this situation, but there are still many problems in the financing of small and medium-sized enterprises. This article starts from the existing problems and actively discuss the way to solve these problems.

Keywords: Inclusive Finance; The Financing of Small and Medium-Sized Enterprises (FSMSE); Credit Risks

\section{Introduction}

The development of inclusive finance has received a lot of national attention in recent years. In December 2015, the State Council promulgated the "the Inclusive Finance Development Plan (2016-2020)", which raised the development of inclusive finance to a national strategic level and made its development goal to continuously improve the accessibility of financial services for the disadvantaged. Its main targets include small and medium sized enterprises. Under the present economic condition, the small and medium-sized enterprises have been tested by the difficulty of financing. It is of great significance to study risks and preventive solutions for FSMSE under inclusive finance.

\section{Current situation of FSMSE under inclusive finance}

According to the investigation of FSMSE in China, there is a great demand for financing and the financing frequency is high in the development of small and medium-sized enterprises.But it is difficult to obtain financing on time because of imperfect credit record, inadequate asset mortgage and high credit risk of company. It is hard to support its funding costs even when financing is available.By the end of June 2019, the balance of loans to small and medium-sized enterprises nationwide was 35.63 trillion yuan.In the first half of 2019, the average interest rate on newly issued inclusive small and medium-sized enterprise loans was 6.82\%. The financing of small-sized enterprises in China is difficult, expensive and slow, which is closely related to their existing problems.

\section{The problem of FSMSE under inclusive finance}

There are three common problems in FSMSE under inclusive finance: credit risk, absence and offside of government, imperfect of credit reporting system.

Copyright (C) 2020 Dan Ma

doi: $10.18282 /$ ff.v9i1.830

This is an open-access article distributed under the terms of the Creative Commons Attribution Non-Commercial License

(http://creativecommons.org/licenses/by-nc/4.0/), which permits non-commercial use, distribution, and reproduction in any medium, provided the original work is properly cited. 


\subsection{Problems in small and medium-sized enterprises}

Compared with the steady large-scale enterprises, the small and medium-sized enterprises are small in scale, weak in risk-resisting ability, and imperfect in-house personnel management structure. It does not have a sound financial system. Its related production and operation concept may not be updated in a timely manner. Their credit rating is low, which creates a greater credit risk. The national non performing loan rate for small and medium-sized enterprises is $3.75 \%$, which accounts for a large proportion of the overall non performing loan rate. The small and medium-sized enterprises lack mortgage guarantee, causing a higher financing risk. Moreover, the operating range of the small and medium-sized enterprises is small, with great uncertainty in development prospects. Information lag makes its management and operation can not be updated on time. In addition, the repayment pressure and other multiple issues increase the credit risk of small and medium-sized enterprises.

\subsection{Implications of inclusive finance}

Financial institutions which involved in lending to small and medium-sized enterprises will face low yields and high risks, which limits the participation of financial institutions to some extent. It may be difficult for financial institutions without sufficient capacity to prevent and control risks to get involved. The social responsibility of financial institutions alone can hardly keep the market functioning properly. Therefore, the development of small and medium-sized enterprises under inclusive finance loans can not be separated from government regulation. But for now, government regulation presents a dilemma. On the one hand, excessive government regulation makes the financial market lack of vitality, which may lead to market contraction, increase the cost of corporate financing and waste financial resources. On the other hand, it is difficult to truly ease the financing problem of small and medium-sized enterprises with imperfect laws and regulations in inclusive finance. On the contrary, there will be a "close to death, put on the chaos" phenomenon.

\subsection{Focusing on small and medium-sized enterprises that are relatively weak in financing}

This group has a great risk of default, so its credit needs to be assessed. The assessment data partly come from the report provided by the enterprises themselves, but Chinese citizens' credit consciousness is insufficient and the relevant laws and regulations need to be improved urgently. To sum up, it is very risky to rely mainly on the self-restraint of the enterprise to carry on the credit evaluation. Moreover, some enterprises' own financial system is not perfect, making it difficult for them to provide useful data. Then, the financial institutions themselves will assess the credit of loan enterprise. The rate of return for financial institutions has fallen again, taking into account the cost of assessment. Finally, the ratings provided by the existing credit rating agencies in the Chinese market, which are widespread in the Chinese economy, are overwhelmingly unreliable.

\section{Preventive solutions for FSMSE under inclusive finance in China}

In view of the above three problems, this paper puts forward the following countermeasures.

(1) Small and medium-sized enterprises as the main participants of financing, in the course of operation must keep a positive attitude. First of all, enterprises should improve the internal financial system, ensure the accuracy of internal fund flows and improve financial transparency and credibility, which will ease the information asymmetry between enterprises and borrowers. This can be achieved by hiring professional accountants such as those with CPA certificates and accounting experience. The enterprise itself must establish the positive financial consciousness. Second, small and medium-sized enterprises should also improve the efficiency of funds, rationally allocate funds and strengthen effective capital control. In the course of operation, they should perfect the risk prevention and control mechanism, strengthen the risk assessment, improve the ability of resisting risk, so as to reduce the credit risk of financing and prepare for the next round of financing.

(2) Under inclusive finance, the development of FSMSE can not be done without support from government. The government should play its macroeconomic regulation and control role in the financial market, formulate effective 
financing policies, and reduce the phenomenon of financing inequality and single financing service. The government can increase expenditure in inclusive finance to provide financial support for FSMSE, mitigate the risks arising from market failure and improve financial regulation. The government can actively guide the development and improvement of the financial market to provide a good environment for the financing of small and medium-sized enterprises. It could provide further preferential tax services to boost the incentives of financial institutions. Moreover, the government could delegate professionals to help enterprises develop healthily. The government is the bridge and premise linking enterprises and financial institutions. Only with the correct guidance and supervision of the government, it is possible to solve the problem of FSMSE.

(3) Credit is a prerequisite for the operation of financial markets, and effective information can reduce the credit risk in the financing process and alleviate the problem of information asymmetry. This can be done by establishing rules and regulations to raise the awareness of participants, such as raising the interest rate on loans or not granting loans if the company is found to provide untrue information. The truth of information is the foundation of the operation of inclusive finance. In this section, Zhima Credit of Alipay does very well. Zhima Credit, which is tied to a user's daily life, is rated monthly based on the user's usual behavior. Financial institutions can cooperate with them to mitigate information asymmetry.

\section{Conclusion}

Small and medium-sized enterprises have increasingly become an important part of promoting employment and promoting grass-roots innovation, which is small in scale is small, but great in number and wide in distribution. The development of small and medium-sized enterprises provides a basic guarantee for people's livelihood. Therefore, it is particularly important to support the development of small and medium-sized enterprises. It is urgent to solve the problem of FSMSE, which requires the cooperation of the enterprise itself, the support of financing institutions and the help of the government. The combination of these three parties can build a perfect financial market.

\section{References}

1. Li L. Research on financial risks and counter strategies of small and micro enterprises in China under Internet finance (in Chinese). Economic Research Guide 2019; (24): 83-84.

2. Zhao R. Research on mechanism innovation of inclusive finance (in Chinese). Think Tank Era 2019; (39): 39+55.

3. Wen Y, Zhang X. A preliminary study on the financing mechanism innovation of small and micro enterprises from the perspective of inclusive finance (in Chinese). Economic Research Guide 2019; (24): 88-89.

4. Zhou W, Ling J. Inclusive finance and the financing constraints of SMEs: Evidence from SMEs in China. Collected Essays on Finance and Economics 2018; (6): 34-45.

5. China inclusive financial development report 2019.

6. Zong M. The ethical basis and practical principles of inclusive finance (in Chinese). Zhejiang Social Sciences 2020; (5): 102-110+159-160.

7. The tax incentives were extended for four years (in Chinese). Domestic and Foreign Toy Manufacturing 2020; (5): 76. 